J. Agronomy \& Crop Science 188, 417—425 (2002)

(C) 2002 Blackwell Verlag, Berlin

ISSN 0931-2250

Departments of Agronomy and Plant Genetics, University of Minnesota, St. Paul, MN and USDA-ARS, St. Paul, $M N, U S A$

\title{
Evaluation of Annual Medicago for Upper Midwest Agroecosystems
}

\author{
R L. De Haan, C. C. Sheaffer, D. A. Samac, J. M. Moynihan and D. K. Barnes
}

Authors' addresses: Dr R. L. De Haan, Agriculture Department, Dordt College, Sioux Center, IA, USA; Dr C. C. Sheaffer (corresponding author; e-mail: sheaf001@umn.edu), Department of Agronomy and Plant Genetics, 411 Borlaug Hall, 1991 U. Buford Circle, University of Minnesota, St. Paul, MN 55108, USA; Dr D. A. Samac, USDA-Agricultural Research Service, University of Minnesota, St. Paul, MN, USA; Dr J. M. Moynihan, Minnesota Department of Agriculture, St. Paul, MN, USA; Dr D. K. Barnes (Retired), USDA-Agricultural Research Service, University of Minnesota, St. Paul, MN, USA

With 3 tables

Received May 3, 2002; accepted June 11, 2002

\begin{abstract}
Annual Medicago species (medics) have characteristics that may make them a valuable addition to agricultural systems in the Upper Midwest, USA, but few genotypes have been evaluated. The objective of this research was to identify medic germplasm exhibiting traits that are desirable for cultivars intended for multiple uses in the region. Australian annual medic cultivars and plant introductions (PI) representing seven species were evaluated for Phytophthora root rot (Phytophthora medicaginis Hansen et Maxwell) resistance, shade tolerance, growth habit, dry matter accumulation, maturity after 9-10 weeks of growth, and potato leafhopper (Empoasca fabae Harris) yellowing. Medicago polymorpha L. plant introductions PI 197346, PI 459135, and PI 283653 were resistant to Phytophthora root rot. Kelson [Medicago scutellata (L.) Mill.] and PI 419241 [Medicago tornata (L.) Mill.] were tolerant of shade, while M. polymorpha entries Santiago and SA 9032 were intolerant. In growth habit comparisons, PI 419241 and PI 368939 ( $M$. polymorpha) grew less than $11 \mathrm{~cm}$ tall, while Kelson and SA 5762 (M. polymorpha) grew at least $27 \mathrm{~cm}$ tall. Dry matter production 10-12 weeks after emergence was greatest for PI 197339 (M. polymorpha) and Kelson. At that time, the earliest maturing entries, PI 226517 ( $M$. polymorpha) and Sava ( $M$. scutellata), had begun to senesce, while the latest maturing entry (PI 419241) was still vegetative. Paraponto (Medicago rugosa Desr.) was highly resistant to potato leafhopper yellowing. None of the medic entries evaluated combined all of the desirable traits for Upper Midwest cultivars, but the traits were all present within available germplasms. Plant breeders could develop adapted cultivars by combining favourable traits from several medic genotypes.
\end{abstract}

Key words: cover crops - disease and insect resistance - Medicago polymorpha L. - Medicago rugosa Desr. - Medicago scutellata (L.) Mill. - Medicago truncatula Gaertn. - shade tolerance

\section{Introduction}

Annual Medicago species such as Medicago polymorpha L., Medicago rugosa Desr., Medicago scutellata (L.) Mill. and Medicago truncatula Gaertn. are native to regions surrounding the Mediterranean Sea where they grow as winter annuals (Sheaffer 1997). Medic is the common name given to annual Medicago native to that region where average annual rainfall is between 100 and $550 \mathrm{~mm}$ and the soil is alkaline. Medics were accidentally introduced into Australia in the midNineteenth Century and are now widely used in Australian agriculture for forage and green manure crops (Chatterton and Chatterton 1996). However, medics are only used to a limited extent by producers in the USA (Bauchan 2001). In research in the north-central USA, annual medics have been shown to have potential as summer annual forage sources (Zhu et al. 1996, Shrestha et al. 1998), as intercrops with small grains (Moynihan et al. 1996) and smother crops in soybean (Sheaffer et al. 2002), as a source of biologically fixed $\mathrm{N}$ for subsequent crops (Zhu et al. 1998, Sheaffer et al. 2001) and as over-winter cover crops following small grains (Fisk et al. 2001). De Haan et al. (1997) and Jeranyama et al. (1998) showed that annual medics have potential as smother or cover plants in corn (Zea mays L.) production and can contribute $\mathrm{N}$, suppress weeds, and reduce soil erosion. In the aforementioned research, annual medic cultivars imported from Australia were utilized. There has been no selection for traits important for medic adaptation to Midwestern USA environments and agroecosystems. 
Disease and pest resistance will be important for adaptation of annual medics to USA environments. Phytophthora root rot is common throughout the Upper Midwest (Thies 1991) and resistance will be necessary in medic germplasm used in the region. Alfalfa (Medicago sativa L.) has been evaluated for response to this disease and resistant cultivars have been developed (Elgin and Welty 1988). It is likely that some annual medics may also have resistance to Phytophthora root rot but important medic species have not been evaluated for resistance.

Potato leafhopper is an important insect pest of alfalfa in the Upper Midwest (Elden 1991) and causes significant economic loss each year. Medics have not been evaluated specifically for resistance to potato leafhopper, but researchers in Australia, where annual medics are an important forage crop, have identified sources of resistance to the spotted alfalfa aphid (Therioaphis maculata Buckton) and the blue-green aphid (Acyrthosiphon kondoi Shinji) (Crawford et al. 1989). Resistance to these pests is conferred by separate, simply inherited, dominant genes, which have been successfully backcrossed into widely planted Australian medic cultivars. Glandular hairs have been reported in several annual Medicago species (McKee 1918) and are known to confer resistance to potato leafhoppers in alfalfa (Shade et al. 1979). Based on these results, it is possible that potato leafhopper resistance is present in annual medic germplasm and that the trait can be manipulated through plant breeding.

The response of medics to reduced light will be important in determining if they are adapted to intercropping with small grains or row crops. Medics intercropped with small grains to provide ground cover and pasture after grain harvest will need to be shade tolerant to survive under the crop canopy until the small grain is harvested. Conversely, it may be advantageous for medics grown with corn or soybeans (Glycine max L.) to be shade intolerant and to senesce as the crop canopy develops, thus limiting their competitive effects on the crop. Annual medic germplasm has not been evaluated for shade tolerance, but variability for this trait is known to exist among and within other species. Research conducted by Cooper (1967) comparing the relative growth rates of birdsfoot trefoil (Lotus corniculatus L.) and alfalfa under shade levels of $0-92 \%$ indicated that birdsfoot trefoil was more tolerant of shade than alfalfa.

Traits such as plant height and width, life cycle length, and pod type will play a role in determining the agroecological niches in which annual medic cultivars can be successfully grown. Medic varieties planted to produce forage or autumn cover will need to be large and tall, with a late maturing or indeterminate growth habit. Conversely, medics used as smother plants in row crops should be small, prostrate, and early maturing (De Haan et al. 1994). Smooth pods are preferable to spiny pods because they do not become entangled in the wool or hair of animals. Considerable variation for these traits appears to be present in the annual medics. Australian researchers have used this variability to develop a number of medic cultivars (Crawford et al. 1989). The objective of this research was to evaluate medic germplasm for traits that are desirable for cultivars developed for a diversity of Upper Midwest agroecosystems.

\section{Materials and Methods \\ Phytophthora root rot resistance}

Thirty-six medic entries (Table 1) were evaluated for resistance to Phytophthora root rot in a field assay conducted over 2 years at the University of Minnesota Agricultural Experiment Station, St. Paul, MN. Twelve Australian medic cultivars were selected for evaluation because they are being grown commercially and seed is available in large quantities. The USA plant introductions evaluated in this research were selected based on diversity of origin and on their potential usefulness in a breeding programme. The Australian plant introductions included in these experiments were being evaluated for possible release as cultivars in Australia.

The experimental site was originally inoculated in 1968 by spreading infested soil from several geographical areas over the field, incorporating to a depth of $15 \mathrm{~cm}$, and growing a susceptible variety for 1 year (Frosheiser and Barnes 1973). The soil was a Waukegan silt loam (fine-silty, mixed mesic, Typic Hapludoll). The experimental site was mold-board ploughed in the spring, field cultivated, and dragged before planting. Weeds were controlled with a preplant incorporated application of trifluralin (a,a,a-trifluoro-2,6-dinitro$\mathrm{N}, \mathrm{N}$-dipropyl-p-toluidine) at $0.84 \mathrm{~kg}$ a.i. $\mathrm{ha}^{-1}$. Trifluralin controlled many of the annual grass and broadleaf weeds, but was not phytotoxic to annual medics. Annual medic entries were planted during the first week of May in 0.9-m-long rows spaced $0.3 \mathrm{~m}$ apart in year 1 and in 1.5-m-long rows spaced $0.6 \mathrm{~m}$ apart in year 2 . Seeding rate was 130 seeds per row. Medic seeds were inoculated with medic-specific inoculum manufactured by LiphaTech, Inc. (Milwaukee, WI).

In year 1, the Australian cultivars and the Australian plant introductions were evaluated in an experiment separate from the USA plant introductions. In year 2, all entries were evaluated in the same experiment. The experimental design for both years was a randomized complete block with three replications.

Seedlings (alive + dead) were counted when they were in the unifoliolate to first trifoliolate stages. From 4 to 
Table 1: Description and source of Medicago spp. entries evaluated in years 1, 2, and 3 at St. Paul, MN

\begin{tabular}{|c|c|c|}
\hline Cultivar or plant introduction & Scientific name & Source (origin) \\
\hline cv. Harbinger AR & M. littoralis Rohde ex Lois. & Revelle Seeds $\dagger$ (Iran) \\
\hline cv. George & M. lupulina $\mathrm{L}$. & Timeless Seedst (Montana) \\
\hline cv. B2951 & M. polymorpha $\mathrm{L}$. & Revelle Seeds \\
\hline cv. Santiago & M. polymorpha $\mathrm{L}$. & Revelle Seeds \\
\hline cv. Serena & M. polymorpha $\mathrm{L}$. & Revelle Seeds \\
\hline cv. Paraponto & M. rugosa Desr. & Revelle Seeds (Italy) \\
\hline cv. Kelson & M. scutellata (L.) Mill. & Revelle Seeds \\
\hline cv. Sava & M. scutellata (L.) Mill. & Revelle Seeds \\
\hline cv. Rivoli & M. tornata (L.) Mill. & Revelle Seeds \\
\hline cv. Caliph & M. truncatula Gaertn. & Revelle Seeds \\
\hline cv. Mogul & M. truncatula Gaertn. & Revelle Seeds \\
\hline cv. Paraggio & M. truncatula Gaertn. & Revelle Seeds (Italy) \\
\hline cv. Nitro & M. sativa $\mathrm{L}$. & USDA-ARS, St. Paul, MN \\
\hline PI 163369 & M. polymorpha $\mathrm{L}$. & USDA-ARS§ (Ecuador) \\
\hline PI 186329 & M. polymorpha $\mathrm{L}$. & USDA-ARS (Australia) \\
\hline PI 197339 & M. polymorpha $\mathrm{L}$. & USDA-ARS (Australia) \\
\hline PI 197346 & M. polymorpha $\mathrm{L}$. & USDA-ARS (Australia) \\
\hline PI 226517 & M. polymorpha $\mathrm{L}$. & USDA-ARS (Iran) \\
\hline PI 267931 & M. polymorpha $\mathrm{L}$. & USDA-ARS (Iran) \\
\hline PI 283653 & M. polymorpha $\mathrm{L}$. & USDA-ARS (Israel) \\
\hline PI 283656 & M. polymorpha $\mathrm{L}$. & USDA-ARS (Israel) \\
\hline PI 283657 & M. polymorpha $\mathrm{L}$. & USDA-ARS (Sweden) \\
\hline PI 292424 & M. polymorpha $\mathrm{L}$. & USDA-ARS (Israel) \\
\hline PI 368939 & M. polymorpha $\mathrm{L}$. & USDA-ARS (Chile) \\
\hline PI 368951 & M. polymorpha $\mathrm{L}$. & USDA-ARS (Chile) \\
\hline PI 385150 & M. polymorpha $\mathrm{L}$. & USDA-ARS (Spain) \\
\hline PI 459135 & M. polymorpha $\mathrm{L}$. & USDA-ARS (Turkey) \\
\hline PI 478439 & M. polymorpha $\mathrm{L}$. & USDA-ARS (Bolivia) \\
\hline PI 505427 & M. polymorpha $\mathrm{L}$. & USDA-ARS (Spain) \\
\hline PI 419241 & M. tornata (L.) Mill. & USDA-ARS (Greece) \\
\hline SA 1327 & M. polymorpha $\mathrm{L}$. & S. Australia Department of Agriculture \\
\hline SA 4229 & M. polymorpha $\mathrm{L}$. & S. Australia Department of Agriculture \\
\hline SA 5762 & M. polymorpha $\mathrm{L}$. & S. Australia Department of Agriculture \\
\hline SA 9032 & M. polymorpha $\mathrm{L}$. & S. Australia Department of Agriculture \\
\hline SA Z-265 & M. truncatula Gaertn. & S. Australia Department of Agriculture \\
\hline SA 18289 & M. truncatula Gaertn. & S. Australia Department of Agriculture \\
\hline
\end{tabular}

$\dagger$ Revelle Seeds, Dimboola, Victoria, Australia.

+ Timeless Seeds, Conrad, MT.

$\S$ USDA-ARS, Regional Plant Introduction Station, Pullman, WA.

- Department of Agriculture, Adelaide, South Australia, Australia.

6 weeks after planting, the plot was irrigated daily to continuously saturate the soil. Soil was then allowed to dry for 1 week for cultivation for weed control, after which the process was repeated. Medic shoot growth was trimmed to a 10-cm height on 12 August before scoring. On 13 August, medic entries were dug with hand spades and washed, and individual plants were scored for Phytophthora root rot using the system described by Thies and Barnes (1991), where scores of 1 and 2 designate resistant plants, and 3 to 6 susceptible. The percentage of scores of 1 and 2 was calculated for each medic entry, as was the average severity index (ASI). The ASI is the more precise estimate and is calculated as

$$
\begin{aligned}
\mathrm{ASI}= & {[(\text { classes } 1+2) \times(\text { classes } 2+3)} \\
& \times(\text { classes } 3+4) \times(\text { class } 4+5) \\
& \times(\text { classes } 5+6) \times(\text { class } 6)] \\
& /(\text { total number of plants in classes } 1 \text { to } 6)
\end{aligned}
$$

where class 1 , class 2 , etc. indicate the number of plants in the respective class. Data were subject to analysis of variance using GLM in SAS (SAS Institute). Means were separated using LSD (Least Significant Difference) (0.05). 


\section{Shade tolerance, growth characteristics and potato} leafhopper resistance

Field experiments to evaluate the shade tolerance and growth habit of medic genotypes were conducted over 2 years at St. Paul, MN. Soil type and soil preparation were similar to those described for the Phytophtora root rot nursery. Annual medics were seeded in hills on $0.91-\mathrm{m}$ centres on about 20 May. Twelve live seeds per hill were planted at a depth of $5 \mathrm{~mm}$ in a circle $5 \mathrm{~cm}$ in diameter. Annual medic seeds were inoculated with medic-specific inoculum (LiphaTech, Inc., Milwaukee, WI).

The experimental design was a randomized complete block with a split-plot restriction on randomization and four replications. Main plot treatments were full sunlight (control) and application of shade cloths designed to reduce photosynthetically active radiation by 49 and $76 \%$. Subplot treatments were annual medic genotypes.

Main block size was $5.5 \mathrm{~m} \times 5.5 \mathrm{~m}(6$ hills $\times 6$ hills $)$ with hills of 'Santiago' medic seeded as borders around each block. Three weeks after medic emergence, hills were thinned to 8 plants per hill. Three weeks after medic emergence, $7.3 \mathrm{~m}$ by $7.3 \mathrm{~m}$ polyethylene shade cloths were suspended $55 \mathrm{~cm}$ above the ground of main plots requiring shade, and left in place until the end of the growing season.

Height, width, and maturity stage were recorded for each entry 10-12 weeks after emergence. Because of relatively similar responses between years, data were averaged for the 2 years for presentation. Maturity stage was scored using an alfalfa morphological maturity scale (Kalu and Fick 1981) modified for annual medics where $1=$ vegetative stage (no buds, flowers, or pods), 2 = early bud (1-2 nodes with visible buds), $3=$ late bud ( 3 or more nodes with visible bud), 4 = early flower ( 1 node with 1 open flower), $5=$ late flower ( 2 or more nodes with open flowers), $6=$ early seed pod (1-3 nodes with green seed pods), $7=$ late seed pod ( 4 or more nodes with green seed pods), and $8=$ ripe seed pod (nodes with mostly brown mature seed pods). Potato leafhopper yellowing was rated visually using a 1 (plants unaffected) to 5 (100\% of the plants yellowed) scale after 10 weeks of growth in year 1 and year 2. Dry weights of plants in each hill were obtained after 12 weeks of growth in year 1 and after 10 weeks of growth in year 2 .

Pyranometers (LI 200S, LI-COR, Inc., Lincoln, NE) were attached to a CR21 micrologger (Cambell Scientific, Inc., Logan, UT) and mean irradiance was measured every $3 \mathrm{~h}$ under each shade level from 28 July to 4 August in year 1. On 26 July in year 1, and on 24 June in year 2, an LI 1800 spectrophotometer (LI-COR, Inc., Lincoln, NE) measured total photosynthetically active radiation (PAR) in each main plot at $1400 \mathrm{~h}$. On 12 July in year 1 , the LI 1800 spectrophotometer was used to measure total PAR, PAR every $10 \mathrm{~nm}$ from 380 to $800 \mathrm{~nm}$, and red to far-red ratio, at 0830,1200 , and $1730 \mathrm{~h}$ in each main plot. The percentage of total irradiance removed by the shades remained relatively constant throughout the day, indicating that there was little direct light entry into the shaded blocks during early morning and evening hours when the sun angle was low. The ratio of red to far-red light $(660: 730 \mathrm{~nm})$ was similar between shaded and unshaded blocks
Data were analysed by analysis of variance, linear and non-linear regression, and cluster analysis. Cluster analysis was used to group medic entries that responded to shade in a similar manner, and regression analysis was used to present the overall response of medic entries to shade. Specific data on medic dry weight response to shading are not presented.

\section{Results and Discussion Phytophthora root rot resistance}

'Santiago' was more resistant to Phytophthora root rot than the other Australian medic cultivars, but it had an ASI score of 3.8 and only $8 \%$ resistant plants, indicating a relatively low level of resistance (Table 2). The other Australian medic cultivars were very susceptible to Phytophthora root rot. Many of the USA plant introductions had moderate to high levels of resistance to Phytophthora root rot. Among the most resistant entries in both years were PI 197346, 459135, and 505427. Three Australian plant introductions (SA 1327, 5762, and 9032) had moderate levels of resistance to Phytophthora root rot, but the others were very susceptible. All entries with moderate to high levels of resistance to Phytophthora root rot were $M$. polymorpha species. In general, entries with an ASI of 4.0 or more had substantial seedling mortality and had visibly stunted above-ground growth.

These results indicate that commercially available medic cultivars are not likely to perform well if grown in environments where Phytophthora root rot occurs. The high levels of Phytophthora root rot resistance in some $M$. polymorpha USA plant introductions indicate that it will be possible to develop resistant cultivars. Evaluation of additional germplasm will be necessary to determine if resistance genes are present in annual medic species other than $M$. polymorpha.

\section{Shade tolerance}

Shade treatments of 0,49 , and $76 \%$ had a large effect on medic growth and development. Averaged over years, plant yields for the 0 (full sunlight), 49, and $76 \%$ light reduction were 117, 64, and $18 \mathrm{~g} \mathrm{plant}^{-1}$. On average, annual medics grown under 49 or $76 \%$ shade matured more slowly than those grown in full sunlight. Potato leafhopper yellowing was not affected by shade treatments.

The shade responses of the 36 medic entries were grouped by cluster analysis into one of three 
Table 2: Phytophthora root rot resistance and shading tolerance of annual Medicago entries

\begin{tabular}{|c|c|c|c|c|c|c|}
\hline \multirow[b]{3}{*}{ Cultivar or plant introduction } & \multicolumn{4}{|c|}{ Phytophthora root rot } & & \\
\hline & \multicolumn{2}{|c|}{ Year 1} & \multicolumn{2}{|c|}{ Year 2} & \multicolumn{2}{|c|}{ Shading tolerance ${ }^{\#}$} \\
\hline & $\begin{array}{c}\text { Resistant } \\
\text { plants } \dagger(\%)\end{array}$ & ASI & $\begin{array}{c}\text { Resistant } \\
\text { plants }(\%)\end{array}$ & ASI & Year 1 & Year 2 \\
\hline cv. Harbinger AR & 0 & 5.7 & - & - & - & 4 \\
\hline cv. George & - & - & - & - & 3 & - \\
\hline cv. B2951 & - & - & 0 & 4.5 & 3 & 4 \\
\hline cv. Santiago & 8 & 3.8 & - & - & 3 & 5 \\
\hline cv. Serena & 3 & 4.7 & - & - & 3 & 5 \\
\hline cv. Paraponto & 1 & 4.2 & - & - & 3 & 4 \\
\hline cv. Kelson & 1 & 4.5 & - & - & 1 & 2 \\
\hline cv. Sava & 0 & 5.6 & - & - & 1 & 4 \\
\hline cv. Rivoli & - & - & 0 & 5.5 & 3 & 5 \\
\hline cv. Caliph & 0 & 5.4 & - & - & 2 & 5 \\
\hline cv. Mogul & 0 & 5.5 & - & - & 1 & 4 \\
\hline cv. Paraggio & 1 & 5.1 & - & - & 3 & 4 \\
\hline SA 1327 & 22 & 3.8 & - & - & 2 & 5 \\
\hline SA 4229 & 0 & 5.1 & - & - & 3 & 4 \\
\hline SA 5762 & 25 & 3.5 & - & - & 2 & 5 \\
\hline SA 9032 & 23 & 3.8 & - & - & 3 & 5 \\
\hline SA Z-265 & 1 & 4.6 & - & - & 3 & 4 \\
\hline SA 18289 & 0 & 5.4 & - & - & 3 & 4 \\
\hline PI 163369 & 73 & 2.6 & 49 & 3.4 & 3 & 5 \\
\hline PI 186329 & 59 & 2.7 & 39 & 3.3 & - & 5 \\
\hline PI 197339 & 0 & 4.7 & 2 & 4.5 & 3 & 5 \\
\hline PI 197346 & 82 & 2.1 & 65 & 2.9 & 1 & 4 \\
\hline PI 226517 & 8 & 4.4 & 61 & 3.0 & 2 & 4 \\
\hline PI 267931 & 40 & 3.1 & 62 & 2.6 & 2 & 4 \\
\hline PI 283653 & 67 & 2.5 & 47 & 3.2 & 2 & 5 \\
\hline PI 283656 & 48 & 3.0 & 56 & 2.9 & 3 & 5 \\
\hline PI 283657 & 28 & 3.4 & 66 & 2.6 & 2 & 4 \\
\hline PI 292424 & 32 & 3.5 & 26 & 3.6 & 1 & 5 \\
\hline PI 368939 & 71 & 2.8 & 43 & 3.1 & 3 & 4 \\
\hline PI 368951 & 69 & 2.7 & 52 & 3.0 & 3 & 4 \\
\hline PI 385150 & 0 & 5.2 & 0 & 5.3 & 2 & 4 \\
\hline PI 459135 & 66 & 2.7 & 67 & 2.7 & 2 & 5 \\
\hline PI 478439 & 48 & 3.0 & 25 & 3.6 & 3 & 5 \\
\hline PI 505427 & 51 & 3.0 & 74 & 2.6 & 3 & 5 \\
\hline PI 419241 & 11 & 3.8 & 4 & 4.1 & 2 & 1 \\
\hline $\operatorname{LSD}(0.05)$ & 14 & 0.7 & 21 & 0.7 & & \\
\hline
\end{tabular}

$\uparrow$ Percentage of plants rated 1 or 2 on a scale of 1-6 (Thies and Barnes 1991).

+ Average severity index.

\# 1 = relatively shade tolerant, $5=$ relatively shade intolerant.

categories in year 1 (Table 2). Entries within a shade response group were not different from each other, but the response of each group was different from that of the other groups, as determined by full vs. reduced model $F$-tests (Weisberg 1985). The five annual medic entries in shade response 1 (Kelson, Sava, Mogul, PI 197346, and PI 292424) produced more dry weight under $49 \%$ shade than under full sunlight. This unexpected result indicates that, at least under certain environmental conditions, these medic genotypes are adapted to a partially shaded environment. The dry weight of the remaining medic entries was reduced by shade. In general, entries with relatively high dry weight (as a percentage of control) at the $49 \%$ shade level were more tolerant to the $76 \%$ shade level than entries with a low dry weight under $49 \%$ shade. 
The shade response of annual medics in year 2 was very different from that in year 1 . Medic entries were characterized by five different responses to shade (Table 2). Most of the entries fell into response group 4 or 5 , and showed little shade tolerance in year 2. Entries PI 419241 and Kelson had responses of 1 and 2, respectively. A consistent response to shade will be essential if annual medics are to be widely used in intercropping systems in the Upper Midwest. Among the most shade-tolerant entries, based on rank summation over years, were Kelson, PI 419241, and PI 197346. Among the most shade-intolerant entries were Santiago, SA 9032, and PI 163369.

\section{Growth habit, maturity, and dry weight}

The growth habit of the majority of the medics was sprawling or moderately erect (Table 3 ). USA PI nos. 419241 and 368939, however, had very prostrate growth habits, while Kelson and SA 5762 were among the tallest entries. Among the entries with the lowest dry weight per hill were PI 197346 and George, while Kelson, PI 385150, and Rivoli were among those entries with the highest dry weight.

Medic growth stage varied from vegetative to mature pods, indicating that there was a wide range of life cycle lengths among entries. The majority of the medics were in the early to late pod stages. Those that matured the earliest were PI 226517, George, and Sava, while PI 419241 and Kelson matured the latest. Many of the medic entries evaluated had spiny pods, an undesirable trait.

\section{Potato leafhopper resistance}

Potato leafhopper yellowing scores for individual medic entries were similar each year (Table 3). Average scores ranged from 1.3 to 3.7. Paraponto was clearly the most resistant to potato leafhopper, but PI 419241, George, Kelson, and Sava were also quite resistant. Paraponto leaves and stems were densely covered with glandular hairs, which may have been responsible for its high level of resistance to potato leafhopper yellowing. Potato leafhoppers seemed to prefer upright stems to decumbent ones, and this may have influenced the scores of prostrate medic entries.

\section{Invasiveness}

Annual medics are not indigenous to the Midwestern USA and consequently need to be considered for potential to be invasive weeds that have negative economic, ecological, or social impacts. Several systems have been developed to assess the weed/invasiveness risk of a species (e.g. Hiebert 1997, Reichard 2001). Some annual medic species have characteristics including good seedling vigour and a high level of seed production, which have been associated with weediness.

Reichard (2001) indicated that the best predictor of the success of a species as an invader is whether it has established as a weed at other locations with a similar climate. Specifically, medics flourish in dryland areas with a winter rainfall incidence and on soils that tend to be alkaline. They have successfully established in regions outside their native range. For example, medics were believed to have been accidentally introduced into South Australia as contaminants of imported cereal seed from North Africa (Chatterton and Chatterton 1996). They have also become naturalized in areas of California and Texas following introduction as a forage species (Bauchan 2001). However, in over 7 years of medic testing in Minnesota, we have not observed medic persistence or perennial regeneration in agricultural situations. This is probably because Minnesota has a climate with a significant winter cold period and summer-autumn rainfall. Medics are grown as spring or summer annuals. Established plants have consistently failed to overwinter and there has been no regeneration from seed in the year following seeding. Hard seededness is a significant basis for perenniality in Australia, but in Minnesota seed either germinates in the year of seeding or is killed over winter. Also, although plant stature does vary (Table 3), the medic growth habit is relatively prostrate making medics noncompetitive for light vs. taller species.

\section{Conclusions}

Medic genotypes adapted for use in Upper Midwest cropping systems will need to have a combination of desirable traits. Because medics grown in specific agroecological niches will have different optimum or ideal traits, it is necessary to specify the niche in which they will be used, and then search for entries that fit that niche. Based on field evaluation, observation, and agronomic principles we have developed tentative ideotypes (Rasmussen 1987) for medic varieties to be used in specific cropping systems.

Medics intercropped with small grains to provide ground cover or forage after small-grain harvest 
Table 3: Pod type, growth stage, potato leafhopper yellowing, height, width, and dry weight of annual Medicago entries. Values are averaged for two years

\begin{tabular}{|c|c|c|c|c|c|c|}
\hline $\begin{array}{l}\text { Cultivar or plant } \\
\text { introduction }\end{array}$ & $\begin{array}{l}\text { Pod } \\
\text { type } \dagger\end{array}$ & Staget & $\begin{array}{c}\text { Leafhopper } \\
\text { yellow§ }\end{array}$ & $\begin{array}{l}\text { Height } \\
\text { (cm) }\end{array}$ & $\begin{array}{l}\text { Width } \\
\text { (cm) }\end{array}$ & $\begin{array}{c}\text { Dry } \\
\text { weight }(g)\end{array}$ \\
\hline cv. Harbinger AR & 2 & 7.0 & 2.6 & 17 & 78 & 64 \\
\hline cv. George & 2 & 8.0 & 2.0 & 26 & 72 & 50 \\
\hline cv. B2951 & 2 & 6.8 & 3.0 & 27 & 100 & 175 \\
\hline cv. Santiago & 2 & 7.6 & 3.0 & 22 & 129 & 152 \\
\hline cv. Serena & 2 & 7.7 & 3.2 & 23 & 95 & 125 \\
\hline cv. Paraponto & 2 & 6.0 & 1.3 & 28 & 95 & 136 \\
\hline cv. Kelson & 2 & 2.5 & 2.0 & 32 & 111 & 304 \\
\hline cv. Sava & 2 & 7.9 & 2.0 & 26 & 100 & 158 \\
\hline cv. Rivoli & 2 & 6.7 & 2.7 & 26 & 142 & 191 \\
\hline cv. Caliph & 1 & 7.0 & 2.9 & 28 & 83 & 108 \\
\hline cv. Mogul & 1 & 4.0 & 3.4 & 24 & 93 & 90 \\
\hline cv. Paraggio & 1 & 7.1 & 2.6 & 27 & 106 & 143 \\
\hline cv. Nitro (alfalfa) & 2 & 4.8 & 3.3 & 42 & 30 & 30 \\
\hline PI 163369 & 1 & 6.7 & 3.5 & 18 & 90 & 93 \\
\hline PI 186329 & 2 & 5.5 & 2.6 & 27 & 110 & 133 \\
\hline PI 197339 & 2 & 7.0 & 2.6 & 26 & 110 & 127 \\
\hline PI 197346 & 2 & 7.0 & 2.8 & 23 & 48 & 40 \\
\hline PI 226517 & 1 & 7.9 & 3.6 & 16 & 74 & 77 \\
\hline PI 267931 & 1 & 7.4 & 3.0 & 27 & 87 & 99 \\
\hline PI 283653 & 1 & 7.5 & 3.7 & 22 & 85 & 97 \\
\hline PI 283656 & 1 & 7.7 & 3.0 & 15 & 95 & 127 \\
\hline PI 283657 & 1 & 7.4 & 2.3 & 23 & 98 & 145 \\
\hline PI 292424 & 1 & 7.5 & 3.3 & 23 & 84 & 93 \\
\hline PI 368939 & 2 & 7.2 & 2.2 & 11 & 92 & 126 \\
\hline PI 368951 & 2 & 7.8 & 3.5 & 25 & 100 & 111 \\
\hline PI 385150 & 1 & 7.0 & 2.1 & 20 & 100 & 188 \\
\hline PI 459135 & 1 & 6.5 & 2.7 & 21 & 95 & 100 \\
\hline PI 478439 & 2 & 7.2 & 3.0 & 26 & 95 & 80 \\
\hline PI 505427 & 2 & 7.0 & 2.8 & 24 & 83 & 113 \\
\hline PI 419241 & 1 & 1.0 & 1.9 & 7 & 60 & 48 \\
\hline SA 1327 & 2 & 7.3 & 2.8 & 25 & 110 & 123 \\
\hline SA 4229 & 2 & 7.2 & 3.1 & 24 & 85 & 100 \\
\hline SA 5762 & 2 & 7.8 & 3.5 & 30 & 100 & 84 \\
\hline SA 9032 & 1 & 7.7 & 3.0 & 26 & 100 & 141 \\
\hline SA Z-265 & 1 & 7.2 & 2.4 & 20 & 96 & 158 \\
\hline SA 18289 & 1 & 6.5 & 2.8 & 28 & 85 & 141 \\
\hline $\operatorname{LSD}(0.05)$ & 1.1 & 0.5 & 5 & 17 & 54 & \\
\hline
\end{tabular}

$\dagger$ Spiny pods $=1$ and smooth pods $=2$.

+ Numbers are based on a 1-8 maturity scale where $1=$ vegetative stage and $8=$ mature pods. Means are from the $0 \%$ shade treatment only at 9 weeks after emergence.

$\S$ Visual rating from 1 to 5 , where 1 signifies plants unaffected by pests or disease. Numbers are means across 0,47 , and $73 \%$ shade treatments.

should have smooth pods, mature late, grow moderately tall, produce a large amount of dry weight, be very shade tolerant, and be resistant to Phytophthora root rot and potato leafhopper yellowing. None of the medics evaluated met all of these criteria. Paraponto and Kelson may be the medics best adapted to this niche. They have ideal morphological traits, but they are susceptible to Phytophthora root rot.
Medics used as spring-seeded smother plants in row crops such as corn or soybeans should have the following traits: smooth pods, early maturity (after 7-8 weeks of growth), a maximum height of $10 \mathrm{~cm}$, low to moderate dry weight at harvest, shade intolerance, and resistance to Phytophthora root rot and potato leafhopper. None of the medics evaluated fitted these criteria exactly. PI 368939 came the closest, but needs to be earlier maturing 
and more shade tolerant. PI 283656 also showed promise, but it has spiny pods and is susceptible to potato leafhoppers. PI 419241 creates a dense mat of leaves and stems very close to the ground surface, but it has spiny pods, matures very late, is shade tolerant, and is susceptible to Phytophtora root rot.

Medics planted for spring or autumn forage production will need to have smooth pods, medium to late maturity, an upright growth habit, high dry weight at harvest, and resistance to diseases and pests. Santiago may fit this cropping system quite well, except that it matures relatively early and does not grow extremely tall. PI 283657 also deserves consideration because it produced more dry weight at harvest than any other entry with moderate to high levels of resistance to Phytophthora root rot. Generally, most of the medics with high dry weight at harvest were very susceptible to this disease.

This research indicates that none of the currently available medic cultivars has all of the traits necessary for use in Upper Midwest cropping systems. However, it appears that all of the desired characteristics can be found within available medic germplasm. It should be possible to develop adapted cultivars by evaluating large numbers of USA and Australian plant introductions, followed by a selective breeding programme that combines the traits necessary for specific cropping systems.

\section{Zusammenfassung}

\section{Evaluierung von annuellen Medicago für die 'Upper Midwest' Agrarökosysteme}

Annuelle Medicago Arten (Medics) zeichnen sich durch Eigenschaften aus, die nützliche Effekte in den landwirtschaftlichen Systemen des ,Upper Midwest' der USA haben können. Allerdings sind bisher nur wenige Genotypen daraufhin evaluiert worden. Ziel der Untersuchung war die Eingrenzung des Medic-Germplasma-Pools auf ihre multiple Anbaueignung dieser Region. Australische einjährige Medic-Arten und Pflanzenintroduktionen (PI), welche 7 Arten repräsentieren wurden auf die Resistenz gegenüber der Phytophthora-Wurzelfäule (Phytophthora medicaginis Hansen et Maxwell), Schattentoleranz, Wuchstypus, Trockenmasseakkumulation, Reifeverhalten in der 9 bi 10 Wachstumswoche und der Resistenz gegenüber Kartoffelblattlausvergilbung (Empoasca fabae Harris) untersucht. Die Medicago polymorpha L. Pflanzenintroduktionen PI 197346, PI 459135, and PI 283653 waren resistent auf die Phytophthora-Wurzelfäule. Kelson [Medicago scutellata (L.) Mill.] und PI 419241 [Medicago tornata (L.) Mill.] waren schattentolerant, die M. polymorpha L. Eintragungen Santiago und SA 9032 dagegen intolerant. Beim Vergleich des Wuchstypus blieben PI 419241 und PI 368939
(M. polymorpha) unter $11 \mathrm{~cm}$ Höhe, während Kelson und SA 5762 (M. polymorpha) über $27 \mathrm{~cm}$ Wuchshöhe erreichten. Die Trockenmasseproduktion 10 bi 12 Wochen nach dem Auflaufen war am höchsten bei PI 197339 (M. polymorpha) und Kelson. Zu dieser Zeit begannen die frühreifenden Eintragungen PI 226517 (M. polymorpha) und Sava (M. scutellata) zu altern, während der spätreifende Typ PI 419241 noch vegetativ blieb. Paraponto (Medicago rugosa Desr.) war deutlich resistent gegenüber der Kartoffelblattlausvergilbung. Keine der evaluierten Medic-Introduktionen zeigten die wünschenswerten Kombinationseigenschaften für den ,Upper Midwest' der USA auf, doch sie waren im Germplasma-Pool vorhanden. Die Pflanzenzüchung könnte auf dieser Basis adaptierte Kombinationstypen entwickeln, die mehrere nützliche Eigenschaften der untersuchten Medic-Genotypen aufweisen.

\section{References}

Bauchan, G. R., 2001: Annual medics: what are they and where might they fit into forage and farming systems? In: Agronomy Abstracts, p. 91. ASA, CSSA, SSSA, Madison, WI.

Chatterton, L., and B. Chatterton, 1996: Sustainable Dryland Farming. Cambridge University Press, Cambridge.

Cooper, C. S., 1967: Relative growth of alfalfa and birdsfoot trefoil seedlings under low light intensity. Crop Sci. 7, 176-178.

Crawford, E. J., A. W. H. Lake, and K. G. Boyce, 1989: Breeding annual Medicago species for semiarid conditions in southern Australia. Adv. Agron. 42, $399-437$.

De Haan, R. L., D. L. Wyse, N. J. Ehlke, B. D. Maxwell, and D. H. Putnam, 1994: Simulation of spring-seeded smother plants for weed control in corn (Zea mays). Weed Sci. 42, 35-43.

De Haan, R. L., C. C. Sheaffer, and D. K. Barnes, 1997: Effect of annual medic smother plants on weed control and yield in corn. Agron. J. 89, 813-821.

Elden, T. C., 1991: Potato leafhopper (PLH) tolerance. In: C. C. Fox, R. Berbert, F. A. Gray, C. R. Grav, D. L. Jessen and M. A. Peterson (eds), Standard Tests to Characterize Alfalfa Cultivars, 3rd edn, pp. 1-5. North American Alfalfa Improvement Conference, Beltsville, MD.

Elgin, J. H. Jr, R. E. Welty and D. B. Gilchrist, 1988: Breeding for disease and nematode resistance. In: R. R. Hill, G. H. Heichel, A. A. Hanson and D. K. Barnes (eds), Alfalfa and Alfalfa Improvement, pp. 827-858. ASA, CSSA, SSSA, Madison, WI.

Fisk, J. W., O. B. Hesterman, A. Shrestha, J. J. Kells, R. R. Harwood, J. M. Squire, and C. C. Sheaffer, 2001: Weed suppression by annual legume cover crops in no-tillage corn. Agron. J. 93, 319-325.

Frosheiser, F. I., and D. K. Barnes, 1973: Field and greenhouse selection for Phytophthora root rot resistance in alfalfa. Crop Sci. 13, 735-738. 
Hiebert, R. D., 1997: Prioritizing invasive plants and planning for management. In: J. O. Luken, and J. W. Thieret (eds), Assessment and Management of Plant Invasions, pp. 195-212. Springer, New York.

Jeranyama, P., O. B. Hesterman, and C. C. Sheaffer, 1998: Medic planting date effect on dry matter and nitrogen accumulation when clear-seeded or intercropped with corn. Agron. J. 90, 616-622.

Kalu, B. A., and G. W. Fick, 1981: Quantifying morphological development of alfalfa for studies of herbage quality. Crop Sci. 21, 267-271.

McKee, R., 1918: Glandular pubescence in various Medicago species. J. Am. Soc. Agron. 10, 159-162.

Moynihan, J. M., S. R. Simmons, and C. C. Sheaffer, 1996: Intercropping annual medic with conventional height and semi-dwarf barley grown for grain. Agron. J. 88, 823-828.

Rasmussen, D. C., 1987: An evaluation of ideotype breeding. Crop Sci. 27, 1140-1146.

Reichard, S., 2001: The search for patterns that enable prediction of invasion. In: R. H. Groves, P. H. Graves, F. D. Panetta, J. G. Virtue, (eds), Weed Risk Assessment, pp. 10-19. CSIRO Publishing, Collingwood, VIC, Australia.

SAS Institute, 1993: SAS/STAT User's Guide, Release 6.08. SAS Institute, Cary, NC.

Shade, R. E., M. J. Doskocil, and N. P. Maxon, 1979: Potato leafhopper resistance in glandular-haired alfalfa species. Crop Sci. 19, 287-289.

Sheaffer, C. C., and A. W. H. Lake, 1997: Legumes in cropping systems: approaches in Midwest United
States and Southern Australia In: J. G. BuchananSmith, L. D. Bailey, and P. McCaughey (eds), Proceedings of the XVIII International Grassland Congress, pp. 349-354. Association Management Centre, Calgary, Canada.

Sheaffer, C. C., J. R. Gunsolus, J. Grimsbo Jewett, and S. H. Lee, 2002: Annual Medicago as a smother crop in soybean. J. Agron. Crop Sci. 188, 408-416.

Sheaffer, C. C., S. R. Simmons, and M. A. Schmitt, 2001: Annual medic and berseem clover dry matter and nitrogen production in rotation with corn. Agron. J. 93, 1080-1086.

Shrestha, A., O. B. Hesterman, J. M. Squire, J. W. Fisk, and C. C. Sheaffer, 1998: Annual medics and berseem clover as emergency forages. Agron. J. 90, 197-201.

Thies, J. A., and D. K. Barnes, 1991: Phytophthora root rot resistance. In: C. C. Fox, R. Berbert, F. A. Gray, C. R. Grav, D. L. Jessen, and M. A. Peterson (eds), Standard Tests to Characterize Alfalfa Cultivars, 3rd edn, p. D-8. North American Alfalfa Improvement Conference, Beltsville, MD.

Weisberg, S., 1985: Applied Linear Regression, 2nd edn. John Wiley \& Sons, New York.

Zhu, Y., C. C. Sheaffer, and D. K. Barnes, 1996: Forage yield and quality of annual Medicago species in the north-central USA. Agron. J. 88, 955-960.

Zhu, Y., C. C. Sheaffer, M. P. Russelle, and C. P. Vance, 1998: Dry matter accumulation and dinitrogen fixation of annual Medicago species. Agron. J. 90, $103-108$. 